\title{
Relationship Between the Level of Physical Activity and the Incidence of Dementia in the Elderly
}

\author{
Elis Noviati ${ }^{*}$, Tuti Hidayati ${ }^{b}$, Resna Litasaric, Reffi Nantia Khaerunnisad, Yanti Srinayantie, Lilis \\ Lismayantig, and Heri Ariyantog \\ STIKes Muhammadiyah Ciamis, Indonesia \\ aelisnoviati@gmail.com; bhdyttuti19-9@gmail.com; clitasari76@gmail.com; \\ dreffinantiakhaerunnisa@gmail.com; ezeevanayanti80@gmail.com; flismayantililis2@gmail.com; \\ gariyantoheri7@gmail.com \\ *Correspondence: elisnoviati@gmail.com \\ Type of the Paper (Article)
}

Received: October 28, 2020; Accepted: December 28, 2020; Published: March 14, 2021 https://doi.org/10.29253/achnr.2020.22653

\begin{abstract}
Background: Dementia is a symptom of a decline in memory, thinking, behavior, and ability to perform everyday activities. One of the risk factors for dementia is physical activity. Good physical activity in the elderly can reduce the risk of dementia. Purpose : This study is to determine the relationship between the level of physical activity and the incidence of dementia in the elderly. Method: This study was an analytical association/correlation with a cross-sectional approach, with a total sample of 51 pages. The research instrument used PASE (Physical Activity Scale for Elderly) to measure the level of physical activity and MoCa (Montre al Cognitive Assessment) to assess cognitive function. Findings: The 15 respondents with a low level of physical activity, 13 respondents (86.7\%) had dementia and 2 respondents (13.3\%) of them did not have dementia. While 36 with good activity levels, 2 respondents (5.6\%) developed dementia and 34 respondents (94.4\%) had no Amendment I a. The statistical test used was the chi-square test $(\mathrm{p}=0.00)$. There is a significant relationship between the level of physical activity and the incidence of dementia in the elderly. Also obtained an OR value of 0.009 , meaning that physical activity that is less has a risk of 0.009 times experiencing dementia. Research limitations: Further research can be developed by conducting more specific research on the risk factors that can cause dementia. Originality: The different from previous research, namely, in the research method, research instrument, time, and the title is taken.
\end{abstract}

Keywords: physical activity; dementia

\section{Introduction}

United States statistical data reported that the number of elderly people in the world by the age group in January 2018 was 2.75 billion from 7.53 billion people. WHO (World Health Organization) noted that in Southeast Asia the elderly population was $8 \%$ or about 142 million people. In 2000 the number of elderly people was around 5,300,000 (7.4\%), in 2010 around 24,000,000 (9.77\%), and in 2020 was estimated to reach 20,800,00 (11.34\%) of the total population (Zhao et al., 2019). In 2017 there were 23.66 million elderly people in Indonesia (9.03\%) and in 2018 the number of elderly people reached 24.7 million while the elderly population in West Java in 2015 was 3.77 million and in 2017 as many as 4.17 million (Fitri et al., 2020).

Copyright@ 2020 by the authors. Submitted for open access publication under the terms and conditions of the Creative Commons Attribution (CC BY) license. 
The incidence figure of dementia increases along with the age (Brodaty et al., 2016). After 65 years of age, the prevalence of dementia increases doubles every 5 years of age (Lee et al., 2019). In 2016, WHO recorded that as many as 4.7 million people in the world had dementia, in 2030 the number is estimated to increase by 75.6 million and 135.5 million in 2050 (Kusumaningsih et al., 2020). Each year there are 7.7 million cases of dementia and a new case every 4 seconds (Szabo-reed et al., 2019). The prevalence of dementia in Indonesia is 1.2 million in 2017, the number is expected to increase to 4 million in 2050 (Mulyadi;, Asep, Fitriana; , Anisa, \& Rohaedi, 2020).

Dementia is a syndrome of decreased in memory, thinking, behavior, and the ability to carry out daily activities (Shih et al., 2019). Dementia will start slowly and get worse, so that this condition is initially not realized (Louis et al., 2017). There is a decrease in memory, the ability to remember time, recognize people, places and objects (Rodgers et al., 2018). Early symptoms are usually mild cognitive decline, deterioration in learning new things, the ability to remember events that have just happened (recent memory), or those that have happened long time ago (remote memory), and difficulty finding the right words (Najar et al., 2019).

Dementia is not part of the normal aging process and is not something that will definitely happen in future life (Atherton et al., 2016). Elderly people forget their age is not a sign of dementia or early stage Alzheimer's disease but normal changes in the elderly that will not affect function (Letellier et al., 2019). In normal aging, a person can forget the details, and then completely new events that have newly occurred (Matsunaga et al., 2017). The classic course of dementia is a gradual worsening of 5 to 10 years which eventually leads to death (Chen et al., 2020). Patients with early onset of dementia are likely to have a rapid course of disease, the risk of dementia increases with increasing age, after the age of 65 years, dementia doubles every 5 years of age and this is a major factor in the elderly getting dementia (Moon et al., 2016).

One of the factors that contribute to the occurrence of dementia is physical activity (Krell-roesch et al., 2018). Physical activity is the movement of limbs that causes energy expenditure which is very important for maintaining physical and mental health, as well as maintaining the quality of life to stay healthy and fit throughout the day (Solis-urra et al., 2020). Physical activity plays a very important role, especially for the elderly, by doing physical activity, the elderly can maintain and even improve their health status (Telenius et al., 2015). Physical activity plays a role in cognitive function (Guure et al., 2017). In relation to physical activity, there are elements of motion that function to prepare the brain for optimal learning. By moving, blood flow to the brain is so higher that the supply of nutrients is better (Thapa et al., 2020).

Regular physical activity can improve reaction power, concentration, health, and mental health which can also reduce the risk of dementia in the elderly, one of which is influenced by physical activity (Henskens et al., 2018). Physical activity has four main dimensions, namely type, frequency, duration, and intensity. It would be better if physical activity in the elderly is carried out three times a week with 30 minutes duration (Farioli-vecchioli et al., 2018). This will influence the increase in cognitive function by $20 \%$ in executive control processes such as planning, scheduling, control disorders, and work task coordination (Quan et al., 2017). The purpose of this study was to see the relationship between the level of physical activity and the incidence of dementia in the elderly in the health work area of the Handapherang Health Center.

\section{Literature Review}

Physical activity is the movement of the limbs that causes the expenditure of energy which is very important for maintaining physical and mental health, as well as maintaining the quality of life to stay healthy and fit throughout the day. Physical activity plays a very important role, especially for the elderly. Most of the elderly reduce the amount of physical activity because they think that physical activity is not compatible with their lifestyle even though some of them are aware of its benefits (Shih et al., 2019). In addition, most of the elderly have experienced a decline in health, so they can no longer do physical activity, whereas by strong physic, the elderly can live more prosperously so they do not have dependence on other people (Henskens et al., 2018).

Physical activity is directly related to improving the plasticity of brain synapsis and cognitive function, by doing physical activity there will be vasodilation of blood vessels and an increase in heart rate, with an increase in blood circulation causing a smooth supply of nutrients and oxygen to the brain, 
optimal brain function, and memory ability or short-term memory increases and increases nerve growth factor (NGF) activity, this nerve growth factor is a small protein that is important in the growth and maintenance of nerve cells. Regular physical activity is an effective and beneficial non-pharmacological approach for the elderly (Xu et al., 2017). Physical activity has been proven to reduce and delay the risk of neurodegenerative disorders such as Alzheimer's and dementia (Gallaway et al., 2017).

The impact of dementia is a deterioration of cognitive and memory functions which make the elderly dependent, unable to carry out normal activities, physical activity is disturbed, cannot maximize the spiritual fulfillment due to deterioration of memory and cognitive functions which makes the elderly experience time disorientation (Szabo-reed et al., 2019). Several references both from research and theory obtained from various journals regarding the effect of physical activity on cognitive function, there is a relationship between physical activity and cognitive function. Considering with this condition, itis necessary to be further analyzed so that the quality of life of the elderly is better (Rodgers et al., 2018).

\section{Methodology}

This study used a correlation analytic design with a cross-sectional approach. The population in this study was $\geq 65$ elderly people in the PUSBILA or Elderly Consultation Center of Handapherang Public Health Center area. Those who meet the inclusion criteria are as follows: elderly people $\geq 65$ and elderly people who are willing to be respondents, while the exclusion criteria are characteristics of members of the population that cannot be taken as a sample. Elderly who was sick during the study. The population in this study was 191 elderly with the sampling technique using proportional random sampling, thus the sample obtained was 51 elderly with 9 male and 42 females. The instrument used in the dependent variable is the MoCa (Montreal Cognitive Assessment) to assess cognitive functions, while the independent variable used the PASE (Physical Activity Scale for Elderly) to measure the level of physical activity. This research was conducted in the work area of Handapherang Public Health Center area from 29 November to 17 February 2020. The flow of data processing included editing, coding, cleaning, tabulating using the SPSS program version 20 and the excel program 2010 and for analyzing the results of the assessment used the chi-square statistical test with level of significance $\rho<0.05$.

\section{Result}

\subsection{Univariate Analysis}

\section{Respondent Characteristics}

Table 1. Frequency distribution of respondents by age in the working area of the Handapherang Public Health Center UPTD.

\begin{tabular}{ccc}
\hline Age & Frequency (people) & Percentage (\%) \\
\hline $60-74$ years & 43 & 84.3 \\
$75-90$ years & 8 & 15.7 \\
\hline Total & 51 & 100 \\
\hline
\end{tabular}

Based on table 1 above, it was recognized that the average age of the respondents was between 6074 years, namely as many as 43 people (84.3\%). 
Physical Activity of the Elderly

Table 2. Frequency distribution of Respondents Based on Physical Activity in the Work Area of the Handapherang Health Center UPTD.

\begin{tabular}{ccc}
\hline Physical Activity & Frequency (people) & Percentage $\%$ \\
\hline Good & 36 & 70.6 \\
Less & 15 & 29.4 \\
\hline Total & 51 & 100 \\
\hline
\end{tabular}

The results showed that most of the respondents had good physical activity as many as 36 people $(70.6 \%)$.

Incidence of Dementia in the Elderly

Table 3. Frequency Distribution of Respondents Based on the Incidence of Dementia in the Work Area of the Handapherang Health Center UPTD.

\begin{tabular}{ccc}
\hline The Incidence of Dementia & Frequency (people) & Percentage $\%$ \\
\hline Dementia & 15 & 29.4 \\
Non Dementia & 36 & 70.6 \\
\hline Total & 51 & 100
\end{tabular}

Based on table 4.4 above, of all elderly people who were respondents in this study, the respondents who experienced dementias were 15 people (29.4\%).

\subsection{Bivariate Analysis}

\section{Chi-Square Statistical Test}

Table 4. Relationship between the level of physical activity and the incidence of dementia in the elderly in the working area of the Handapherang Public Health Center UPTD in 2020.

\begin{tabular}{|c|c|c|c|c|c|c|c|c|}
\hline \multirow{3}{*}{$\begin{array}{l}\text { Physical } \\
\text { Activity }\end{array}$} & \multicolumn{4}{|c|}{ The Incidence of Dementia } & & & \multirow{3}{*}{ OR $(95 \% \mathrm{CI})$} & \multirow{3}{*}{$P$ value } \\
\hline & \multicolumn{2}{|c|}{ Non Dementia } & \multicolumn{2}{|c|}{ Dementia } & \multicolumn{2}{|c|}{ Cumulative } & & \\
\hline & $\mathbf{F}$ & $\%$ & $\mathbf{F}$ & $\%$ & $\mathbf{F}$ & $\%$ & & \\
\hline Good & 34 & 94.4 & 2 & 5.6 & 36 & 100.0 & 0.009 & \\
\hline Less & 2 & 13.3 & 13 & 86.7 & 15 & 100.0 & $(0,0010,071)$ & 0.000 \\
\hline Amount & 36 & 70.6 & 15 & 29.4 & 51 & 100.0 & & \\
\hline
\end{tabular}

Based on Table 4 above, it was known that the incidence of dementia based on the level of physical activity in the Handapherang Public Health Center UPTD in 2020 showed a cross table between physical activity and the incidence of dementia with the number in each cell. Based on good physical activity, there were 2 people with dementia (5.6\%) and 34 people without dementia (94.4\%) with a total of 36 people $(100 \%)$. Based on lack of physical activity, 13 people (86.7\%) had dementia and 2 people (13.3\%) who did not experience dementia for a total of 15 people (100\%).

The results of the bivariate analysis statistical test showed that a $p$ value of 0.000 , this indicated that there was a relationship between physical activity and the incidence of dementia in the elderly ( $p \leq 0.05)$. From the analysis results, it was also obtained an OR value of 0.009 , it meant that less physical activity had a risk of 0.009 times experiencing dementia.

\section{Discussion}

The results showed that most of the respondents were elderly aged 60-74 years, as many as 43 people $(84.3 \%)$. This was in line with previous research conducted in Jakarta, where the numbers of respondents aged 60-70 years were 180 people (62.9\%) from 286 respondents. Along with increasing 
age, there was also a decrease in organ function and a decrease in the body's physiological reserves, making it more susceptible to disease (Krell-roesch et al., 2018).

Physical activity is the movement of limbs that causes energy expenditure which is very important for maintaining physical, mental and cognitive health in the elderly. Physical activity can stimulate nerves so that it can inhibit cognitive decline that can lead to dementia (Prick et al., 2016). Cognitive function in older people who are physically active is similar to that of young people and significantly better than those who are not physically active (Yates et al., 2017).

The results of this study indicated that the average elderly had good physical activity, as many as 36 people (70.6\%) of 51 respondents. From the results of interviews conducted by researchers, it was found that some elderly people were still very active in carrying out physical activities such as gardening and walking every morning. This research was supported by previous research which showed that most of the elderly were still active in physical activity, which was $80.6 \%$.

Meanwhile, of the 51 respondents who were lacked physical activity had dementia as many as 15 people $(29.4 \%)$ and those with good physical activity did not experience dementia as many as 36 people (70.6\%). This was in line with previous research which stated that the elderly who did not do physical activity had a 1.4 to 1.6 times greater risk of having poor cognitive function which could increase the risk of dementia compared to people who did physical activity.

Based on the lack of physical activity of the elderly, $86.7 \%$ of the elderly who experienced dementia stated that the incidence of dementia was higher in respondents who had less physical activity than respondents who had good physical activity, physical activity could prevent deterioration of cognitive function due to function poor cognition was a predictor of mortality and could also be seen as a marker of general health status in people with dementia.

Based on the results of data analysis which was obtained from the results of statistical tests using chi-square that could be used to fnd out $p$-value, there were several rules considering with the table above was $2 \times 2$, and there was a value of $E<5$ in one of the cells, so the value of $E$ was the expected, then the test should be fisher's exact test. The results of the bivariate analysis showed that p-value of 0.000 , namely when it was compared with the value $(\alpha)$ of 0.05 , it meant that there was a relationship between physical activity and the incidence of dementia in the elderly. From the analysis results, it was also obtained an OR value of 0.009 , it meant that physical activity which had less risk was 0.009 times experiencing dementia.

This was in line with previous research which showed that physical activity played a role in cognitive function that could prevent dementia, as proven by the respondents, who performed good physical activity, did not experience dementia. The results of statistical analysis using the Spearman Rho test obtained a $p$ value of 0.00 which indicates $<0.05$. This meant that there was a significant relationship between physical activity and the incidence of dementia in the Jember Elderly Social Service Unit (Effendi, Mardijana, \& Dewi, 2014).

\section{Conclusion}

There is a relationship between the level of physical activity and the incidence of dementia in the elderly in the working area of the Handapherang Health Center with a p-value of $0.00<\alpha 0.05$. From the above studies that physical activity facilitates neurotransmitter metabolism, resulting the tropic factors that stimulate the neurogenesis process, increase stimulation of molecular and cellular activity in the brain which in turn supports and maintains brain plasticity. These processes are important to inhibit the hypertrophy of brain networks which can cause neuronal degeneration which impact to the decreased cognitive function that can lead to dementia.

In this study, researcher still have many limitations, researchers only examine the risk factors that cause dementia in general, it is hoped that the next researchers can conduct more specific research on risk factors that can cause dementia both from physical activity, age, gender, diabetes mellitus, blood pressure and genetic factors.

\section{Acknowledgment}

This research can be carried out well with the help of various parties. For this reason, the researchers would like to thank all those who have contributed to this research. 


\section{References}

Atherton, N., Bridle, C., Brown, D., ... Lamb, S. E. (2016). Dementia and Physical Activity ( DAPA ) - an exercise intervention to improve cognition in people with mild to moderate dementia: study protocol for a randomized controlled trial. Trials, 17(165), 1-12. https://doi.org/10.1186/s13063-016-1288-2

Brodaty, H., Woolf, C., ... Sachdev, P. S. (2016). ICC-dementia ( International Centenarian Consortium - dementia ): an international consortium to determine the prevalence and incidence of dementia in centenarians across diverse ethnoracial and sociocultural groups. BMC Neurology, 16(52), 1-10. https://doi.org/10.1186/s12883-016-0569-4

Effendi, A. D., Mardijana, A., \& Dewi, R. (2014). Hubungan antara Aktivitas Fisik dan Kejadian Demensia pada Lansia di UPT Pelayanan Sosial Lanjut Usia Jember. E-Jurnal Pustaka Kesehatan, 2(2), 332-336.

Farioli-vecchioli, S., Sacchetti, S., Robilant, V, N., ... Debora. (2018). The Role of Physical Exercise and Omega-3 Fatty Acids in Depressive Illness in the Elderly. Current Neuropharmacology, 16(3), 308-326. https://doi.org/10.2174/1570159X15666170912113852

Fitri, M., Rahmi, U, Pitriani, P., \& Sulastri, A., (2020). Effectiveness of the brain vitality exercise on physical fitness in $\begin{array}{lllll}\text { elderly with } & \text { dementia. SPORTIF, }\end{array}$ https://doi.org/https://doi.org/10.29407/js_unpgri.v6i2.14360

Gallaway, P. J., Miyake, H., Buchowski, M. S., Shimada, M., Yoshitake, Y., Kim, A. S., \& Hongu, N. (2017). brain sciences Physical Activity : A Viable Way to Reduce the Risks of Mild Cognitive Impairment, Alzheimer' s Disease , and Vascular Dementia in Older Adults. Brain Sciences Review, 7(22), 1-16. https://doi.org/10.3390/brainsci7020022

Guure, B, C., Ibrahim, A, N., Adam, M. B., \& Said, S. (2017). Impact of Physical Activity on Cognitive Decline, Dementia , and Its Subtypes: Meta-Analysis of Prospective Studies. BioMed Research International, (1), 1-13. https://doi.org/10.1155/2017/9016924

Henskens, Marinda, C, I. M., C.A., N. M., Eekeren, V., Scherder, \& J.A., E. (2018). Effects of Physical Activity in Nursing Home Residents with Dementia: A Randomized Controlled Trial. Dementia and Genetic Congnitive Disorders, 60-80. https://doi.org/10.1159/000491818

Ke-hau, C., Hsiu-hui, C., Lin, L., ... Nai-Ching, C. (2020). The impact of exercise on patients with dementia. Medicine, 23(19), 1-7. https://doi.org/http://dx.doi.org/10.1097/

Krell-roesch, Janina, Feder, T, N., Roberts, O, R., \& Mielke, M. M. (2018). Leisure-Time Physical Activity and the Risk of Incident Dementia : The Mayo Clinic Study of Aging. Journal of Alzheimer's Disease, 63(18), 149-155. https://doi.org/10.3233/JAD-171141

Kusumaningsih, A., Yusuf, Ah., \& Suhardiningsih, AV. S. (2020). The Effect of Social Leisure Activity for Decreased Risk of Wandering on Dementia Elderly in Mental Health Hospital Dr . Radjiman Wediodiningrat Lawang Malang. Scientific Journal of Nursing, 6(1), 1-10.

Lee, J. R., Suh, S. W., Han, J. W., Byun, S., Kwon, S. J., Lee, K. H., ... Ryu, S. (2019). Anhedonia and Dysphoria Are Differentially Associated with the Risk of Dementia in the Cognitively Normal Elderly Individuals: A Prospective Cohort Study. Korean Neuropsychiatric Association, 16(18), 575-580. https://doi.org/https://doi.org/10.30773/pi.2019.06.07

Letellier, N., Carrière, I., Gutierrez, L, ... Berr, C. (2019). Influence of activity space on the association between neighborhood characteristics and dementia risk: results from the 3-City study cohort. BMC Geriatrics, 19(4), 1-11. https://doi.org/10.1186/s12877-018-1017-7

Louis, Elan D., MD, MSa, Collins, K., ... Cosentino, S. (2017). Self-reported Physical Activity in Essential Tremor: Relationship with Tremor, Balance, and Cognitive Function. Journal Neurology Sci, 1(203), 240-245. https://doi.org/10.1016/j.jns.2016.05.034.Self-reported

Matsunaga, T., Naito, M., Wakai, K., Ukawa, S., Zhao, W .... Tamakoshi, A. (2017). Leisure-time physical activity and risk of disability incidence: A 12-year prospective cohort study among young elderly of the same age at baseline. Journal of Epidemiology. 27(2017): 538-545 DOI: 10.1016/j.je.2016.11.004.

Moon, Y., Lee, H., Namgung, \& Ok-kyoung. (2016). Which Stratum of Urban Elderly Is Most Vulnerable for Dementia? JKMS, 31, 1635-1640. https://doi.org/http://dx.doi.org/10.3346/jkms.2016.31.10.1635

Mulyadi;, Asep, Fitriana; Anisa, L., \& Rohaedi, S. (2020). GAMBARAN AKTIVITAS FISIK PADA LANSIA DEMENSIA DI BALAI PERLINDUNGAN SOSIAL TRESNA WREDA CIPARAY BANDUNG. Jurnal Kepelatihan Olahraga, 9(1), $1-11$.

Najar, Jenna, Ostling, Svante, Gudmundsson, Pia, ... Guo. (2019). Cognitive and physical activity and dementia. Journal Neurology, 92(12), 1322-1330. https://doi.org/10.1212/WNL.0000000000007021

Prick, Anna-, Eva, Jacomine, Lange, D., Erik, ... Pot. (2016). The effects of a multicomponent dyadic intervention on the mood, behavior, and physical health of people with dementia : a randomized controlled trial. Clinical Interventions in Aging, 11, 383-395. https://doi.org/http://dx.doi.org/10.2147/CIA.S95789 
Quan, Minghui, Xun, Pengcheng, Chen, Cheng, ... He, K. (2017). Walking Pace and the Risk of Cognitive Decline and Dementia in Elderly Populations : A Meta-analysis of Prospective Cohort Studies. Journals of Gerontology, 72(2), 266-270. https://doi.org/10.1093/gerona/glw121

Rodgers, Chloe, Rogerson, David, Stevenson, J., \& Porock, D. (2018). Physical activity for people with young- onset dementia and carers: protocol for a scoping review. Systematic Review, 7(36), 1-7. Retrieved from http://creativecommons.org/licenses/by/4.0/

Shih, I., Paul, K., Haan, M., Yu, Y., Ritz, B., \& Francisco, S. (2019). Physical activity modifies the influence of APOE $\varepsilon 4$ allele and type 2 diabetes on dementia and cognitive impairment among older Mexican Americans. Alzheimers Dement, 14(1), 1-9. https://doi.org/10.1016/j.jalz.2017.05.005.Physical

Solis-urra, Patricio, Plaza-diaz, Julio, Á, A. I., Olivares-arancibia, J., ... Abad, F. (2020). The Mediation E ff ect of Self Report Physical Activity Patterns in the Relationship between Educational Level and Cognitive Impairment in Elderly : A Cross-Sectional Analysis of Chilean Health National Survey 2016 - 2017. International Journal of Environmental Research and Public Health, 17(2619), 1-12. https://doi.org/10.3390/ijerph17082619

Szabo-reed, A. N., Vidoni, E., Binder, E. F., Burns, J., Munro, C., Gahan, W. P., ... Lansing, E. (2019). Rationale and Methods for a Multicenter Clinical Trial assessing Exercise and Intensive Vascular Risk Reduction in Preventing Dementia (rrAD Study). Contemp Clin $T$ Rials, 44-54. https://doi.org/10.1016/j.cct.2019.02.007.Rationale

Telenius, Elisabeth, Wiken, Engedal, Knut, \& Bergland, A. (2015). Long-term effects of a 12 weeks high- intensity functional exercise program on physical function and mental health in nursing home residents with dementia: a single blinded randomized controlled trial. BMC Geriatrics, 15(158), 1-11. https://doi.org/10.1186/s12877-015-0151-8

Thapa, Ngeemasara, Kim, Boram, Yang, Ja-gyeong, ... Jang, M. (2020). The Relationship between Chronotype , Physical Activity and the Estimated Risk of Dementia in Community-Dwelling Older Adults. International Journal of Environmental Research and Public Health, 1-10. https://doi.org/10.3390/ijerph17103701

Xu, W., Wang, Fu, H., Wan, Y., Tan, C., Yu, J., \& Tan, L. (2017). Leisure time physical activity and dementia risk : a doseresponse meta- analysis of prospective studies. BMJ Open, 1-10. https://doi.org/10.1136/bmjopen-2016014706

Yates, L., Yates, J., Orrell, M., Spector, A. \& Woods, B. (2017). Cognitive Stimulation Therapy for Dementia: History, Evolution and Internationalism. Routledge.

Zhao, C., Noble, M., James, Marder, K., Hartman, J. S., ... Scarmeas, N. (2019). Dietary Patterns, Physical Activity, Sleep, and Risk for Dementia and Cognitive Decline. Current Neurology and Neuroscience Reports., 7(4), 335-345. https://doi.org/10.1007/s13668-018-0247-9.Dietary 